\title{
POZYCJA S̃WIECKICH \\ W PRACACH PAPIESKIEJ KOMISJI ODNOWY KODEKSU PRAWA KANONICZNEGO
}

Nie ulega wątpliwości ścisły związek zachodzący między działalnością Papieskiej Komisji Odnowy Kodeksu Prawa Kanonicznego, a uchwałami Soboru Watykańskiego II. Sobór ten na nowo opracował teologiczną naukę o świeckich, która ich dowartościowuje. Warto więc rozważyć, jak w tym kontekście projekt nowego prawa przedstawia pozycję prawną świeckich w Kościele. Twórcy projektu nowego prawa, proponując normy dotyczące świeckich, w dużej mierze czerpali z nauki Soboru Watykańskiego II i na to zwrócono uwagę $w$ artykule. Artykuł zamierza głównie przedstawić projektowane normy dotyczące świeckich.

Artykuł jest pisany w czasie, kiedy Papieska Komisja jest jeszcze w pełni swej działalności, chociaż można przypuszczać, że zasadniczą pracę ma już za sobą. Toteż pewne zagadnienia mogą jeszcze ulec zmianie i mogą być lepiej opracowane. Artykuł oparty jest wyłącznie na pracach Papieskiej Komisji Odnowy Kodeksu Prawa Kanonicznego, opublikowanych w wydawanym przez nią periodyku "Communicationes", oraz na schematach przesłanych kompetentnym instytucjom do konsultacji.

\section{ZARYS DZIAEALNOSCI PAPIESKIEJ KOMISJI ODNOWY KODEKSU PRAWA KANONICZNEGO}

Dnia 25 stycznia 1959 r. papież Jan XXIII oznajmił zamiar zwołania Soboru Powszechnego i przeprowadzenia reformy Kodeksu Prawa Kanonicznego. W ezasie trwania Soboru Watykańskiego II, po jego pierwszej sesji dnia 28 marca 1963 r. papież Jan XXIII ustanowił Papieską Komisję Odnowy Kodeksu Prawa Kanonicznego, która objęła kardynałów. Papież Paweł VI dnia 17 IV 1964 r. powołał organ doradczy Komisji, 
składający się z konsultorów. Do ich grona weszli najwybitniejsi znawcy teologii i prawa kanonicznego, zarówno duchowni jak i świeccy. Przed powołaniem zespołu konsultorów, zwrócono się do poszczególnych Krajowych Konferencji Biskupich, prosząc o wysunięcie kandydatów. Do momentu ukończenia II Soboru Watykańskiego prace Papieskiej Komisji toczyły się powoli, czekano bowiem na promulgację dokumentów soborowych. Wkrótce po zákończeniu Soboru, bo już w styczniu 1966 r., powołano dziesięć zespołów roboczych składających się z konsultorów. Zespoły przyjęły nazwę od tematu, którym się zajmowały. Byı̀y one następujące: „Normy ogólne Kodeksu”, „Duchowni”, „Zakonnicy”, ,,Swieccy”, „Prawo sakramentalne”, „Prawo małżeńskie w szczególności”, „Nauczycielski Urząd Kościoła, „Prawo procesowe”, „Prawo karne”, „Dobra doczesne Kościoła" ${ }^{1}$.

Metoda działania zespołów konsultorskich została ustalona przez przewodniczącego Papieskiej Komisji w dokumencie zwanym „Ordo procedendi" 2. Zgodnie z tym dokumentem i z przyjętą metodą działania, przeważającą ilość pracy kodyfikacyjnej wykonują konsultorzy ${ }^{3}$.

W r. 1966 został ustanowiony zespół centralny, mający za zadanie koordynowanie prac kodyfikacyjnych. W listopadzie $1967 \mathrm{r}$. ustanowiono specjalny zespół konsultorów, zajmujący się przygotowaniem układu systematycznego nowego Kodeksu. W $1968 \mathrm{r}$. powstał nowy zespół dla opracowania fundamentalnego prawa Kościoła. W toku prac pojawiły się jeszcze nowe zespoły, a niektóre istniejące zmieniły nazwę i zakres opracowywanego materiału. Tak np. szczególnie interesujący nas zespół, zajmujący się problematyką świeckich, a noszący nazwę „Swieccy”, zmienił nazwę na „Uprawnienia wiernych, stowarzyszenia i świeccy” 4

Do ożywienia prac Papieskiej Komisji wydatnie przyczynił się Międzynarodowy Kongres Kanonistów zwołany do Rzymu w dniach 20-25 maja 1968 r. z okazji 50-lecia obowiązywalności Kodeksu Prawa Kanonicznego. Kongres został zwołany przez Papieską Komisję Odnowy Kodeksu Prawa Kanonicznego. Wysunięto na nim postulat, aby w specjalnej publikacji informować stale o zamierzonych i wykonanych pracach nad reformą prawa. Spełnieniem tego postulatu stał się periodyk wydawany przez Papieską Komisję od 1969 r., noszący nazwę „Communicationes" ${ }^{5}$.

Zespół konsultorów zwany „Uprawnienia wiernych, stowarzyszenia, świeccy" składał się w 1973 r. z jedenastu członków, w tym trzy osoby

1 Por. P. Felici, Congregatio Plenaria, „Communicationes” 9 (1977) s. 62-63.

2 "Communicationes” 1 (1969) s. 45.

3 Por. W. Góralski, Sprawozdania, "Prawo kanonliczne”, 18 (1975) $\mathrm{nr} 1$-2 s. 211.

4 Por. P. Felici, jw., s. $66-68$.

${ }^{5}$ Por. W. Wójcik. Postęp prac nad rewizja Kodeksu Prawa Kanonicznego „Prawo kanoniczne" 5 (1972) nr $1-2$ s. 277. 
świeckie ${ }^{6}$. Liczba członków poszczególnych zespołów nie jest jednakowa, również ilość osób danego zespołu uległa zmianie, np. zespół zajmujący się świeckimi liczył początkowo dwanaście osób ?.

Obecnie działają następujące zespoły konsultorów:

1. „Fundamentalne prawo Kościoła”;

2. Zespół „Centralny czyli koordynacyjny”;

3. „Układ systematyczny nowego Kodeksu”;

4. "Normy generalne Kodeksu, osoby fizyczne i prawne”;

5. „Hierarchia kościelna”;

6. „Instytuty życia konsekrowanego przez profesję rad ewangelicznych";

7. „Uprawnienia wiernych, stowarzyszenia i świeccy”;

8. „Nauczycielski Urząd Kościoła”;

9. „Sakramenty” (oprócz małżeństwa);

10. „Małżeństwo";

11. „Miejsca i czasy święte oraz kult Boży”;

12. „Dobra doczesne Kościoła”;

13. „Prawo karne”;

14. „Prawo procesowe” ${ }^{8}$.

Interesujący nas materiał dotyczący świeckich w głównej mierze opracowali konsultorzy dwóch zespołów: „Uprawnienia wiernych, stowarzyszenia i świeccy”, oraz „Fundamentalne prawo Kościoła”. Oprócz tych wspominają o świeckich także inne zespoły np. „Hierarchia kościelna” w punkcie o radach duszpasterskich.

\section{OKRESLENIE SWIECKIEGO}

W schemacie „O Ludzie Bożym” jeden z rozdziałów części drugiej nosi tytuł: „Obowiązki i prawa wiernych świeckich”. W pierwszym kanonie tego rozdziału czytamy: „W kanonach bieżącego rozdziału przez świeckich rozumie się wszystkich wiernych, oprócz tych, którzy przez przyjęcie święceń zostali przeznaczeni do wykonywania świętej posługi, albo przez profesję rad ewangelicznych stali się członkami jakiegoś instytutu życia konsekrowanego" ". Zgodnie z podanym tutaj określeniem przez świeckich rozumie się wiernych, którzy nie należą do hierarchii

6 „Communicationes” 5 (1973) s. 191.

7 Por. W. Wójcik, jw., s. 284.

8 P. Felici, jw., s. $68-69$.

9 Pontificia Commissio Codici Iuris Canonici Recognoscendo, Schema canonum libri II „De Populo Dei”, Kan. 523. Tłumaczenie schematu wedlug Ks. E. Sztafrorwskiego, Posoborowe prawodawstwo Kościelne, t. X, z. 2. Również tłumaczenia innych schematów zaczerpnięto z tegoż zbioru. 
i nie są zakonnikami. Analizując określenie świeckich podane w schemacie, narzucają się pewne wątpliwości i zastrzeżenia. Dlaczego użyto sformułowania: „In canonibus huius capitis”, przecież o świeckich wspomina się $\mathrm{w}$ schemacie także $\mathrm{w}$ innych rozdziałach. Wobec tego, jak tam należy rozumieć słowo ,świeccy"? Następnie kanon właściwie nie mówi kim są świeccy, ponieważ tylko stwierdza, że nie mają święceń i że nie są zakonnikami. Jedynie zaznacza się, że są wiernymi „christifideles”. Dlatego trzeba odnieść się do innego miejsca w schemacie, traktująceg J o wiernych: „Mówiąc o wiernych ma się na uwadze tych ludzi, którzy jako wszczepieni przez chrzest w Chrystusa i ustanowieni Ludem Bożym, stawszy się w ten sposób, każdy we własnym zakresie uczestnikami, kapłańskiej, prorockiej i królewskiej funkcji Chrystusa, są powołani każdy zgodnie $\mathrm{z}$ własną pozycją prawną - do wypełniania w świecie misji powierzonej przez Boga Kościołowi" ${ }^{10}$. Podane tutaj określenie wiernych jest bardzo podobne do definicji świeckich, zamieszczonej w dokumentach Soboru Watykańskiego II: „Pod nazwą świeckich rozumie się tutaj wszystkich wiernych chrześcijan nie będących członkami stanu kapłańskiego i stanu zakonnego prawnie ustanowionego w Kościele, mianowicie wiernych chrześcijan, którzy jako wcieleni przez Chrzest w Chrystusa, ustanowieni jako Lud Boży i stawszy się na swój sposób uczestnikami kapłańskiego, prorockiego i królewskiego urzędu Chrystusowego ze swej strony sprawują właściwe całemu ludowi chrześcijańskiemu posłannictwo w Kościele i w świecie" "11. Soborowa definicja laikatu jest pozytywna, świeckich przedstawia się jako Lud Boży, mający do spełnienia swoje specyficzne posłannictwo wewnątrz Kościoła i wobec świata ${ }^{12}$. Swieckiego charakteryzuje się przede wszystkim poprzez określenie go jako aktywnego członka wspólnoty Ludu Bożego, mającego swój udział w całym posłannictwie Kościoła, które jest posłannictwem nie tylko hierarchicznym. Duchowni i świeccy mają wspólny udział w bycie i działaniu chrześcijańskim ${ }^{13}$. Określenie soborowe świeckich zawiera $\mathrm{w}$ sobie następujące elementy pozytywne: $1^{\circ}$ poprzez Sakrament chrztu stają się oni członkami Ciała Chrystusowego i Ludu Bożego, $2^{\circ}$ dzięki temu uczestniczą w Chrystusowym urzędzie kapłańskim, proroczym i królewskim, $3^{\circ}$ zobowiązani są do pełnienia misji zbawczej ${ }^{14}$.

Podane przez schemat „O Ludzie Bożym” określenie świeckich nawiązuje w dużej mierze do przedsoborowego określenia świeckich, jako

10 Schemat „De Populo Dei”, Kan. 16.

11 Konstytucja Soborowa „Lumen gentium”, n. 31, 1.

12 M. Żurowski, Uprawnienia $i$ obowiazki laikatu, [w:] W kierunku człowieka, (pod red. Bohdana Bejze), Warszawa 1971, s. 234.

${ }_{13}$ E. Schillebeecks, Nowy typ człowieka świeckiego, [w:] Nowy obraz Kościoła, (pod red. B. Lamberta), Warszawa 1968, s. 124.

${ }^{14}$ A. Skowronek, Soborowa promocja świeckich w Kościele, „Znak” 20 (1968) s. 64 . 
tych, którzy nie są duchownymi lub zakonnikami. Dopiero w nawiązaniu do kanonu 16 tegoż schematu, określającego wiernych, można utworzyć pozytywne określenie świeckich. Wydaje się, że za podstawę skonstruowania pojęcia ,świeckiego" można wziąć cytowany już n. 31 konstytucji dogmatycznej „Lumen gentium”. który w pierwszej części określa świeckich, a w drugiej podaje ich specyficzne powołanie ${ }^{15}$. Dla zaakcentowania teologicznego dowartościowania świeckich przez Sobór Watykański II należałoby ponadto uwzględnić prawdę o podstawowej równości i godności wszystkich ochrzczonych ${ }^{16}$. Określenie ,,świeckiego" powinno się znaleźć tylko w „,Fundamentalnym prawie Kościoła”, gdyż istnienie stanu świeckich należy do jego konstytucji, a zatem nie jest konieczne w schemacie „O Ludzie Bożym”. Tym bardziej, że schemat „Fundamentalnego prawa Kościoła" podaje określenie świeckich. Określenie to jest poprzedzone stwierdzeniem, że na podstawie ustroju nadanego Kościołowi przez Chrystusa są w nim dwa podstawowe stany: duchowny i świeckich ${ }^{17}$. W następnych kanonach schemat określa duchownych zakonników i świeckich. Przytoczmy określenie świeckich znajdujące się w kanonie 28 projektu „Fundamentalnego prawa Kościoła” ustalonym przez Papieską Komisję w 1979 r.:

„§ 1. Wierni świeccy, którzy nie zostali w szczególniejszy sposób publicznie poświęceni Bogu, uczestniczą w zbawczej misji Kościoła z racji przyjęcia chrztu, który upodobnił ich do Chrystusa oraz bierzmowania, które umocniło ich w wierze.

$\S$ 2. Dają oni również świadectwo Chrystusowi poprzez zajmowanie się sprawami doczesnymi i wypełnianiem świeckich funkcji, układając sprawy ziemskie zgodnie z wolą Bożą" ${ }^{18}$.

15 ,Natomiast zadaniem ludzi świeckich, z tytułu właściwego im powołania, jest szukać Królestwa Bożego zajmując się sprawami świeckimi i kierując nimi po myśli Bożej. Żyją oni w świecie, to znaczy pośród wszystkich razem i poszczególnych spraw i obowiązków świata, i w zwyczajnych warunkach życia rodzinnego i społecznego, z których niejako utkana jest ich egzystencja. Tam ich Bóg powołuje, aby wykonując właściwe sobie zadania, kierowani duchem ewangelicznych przyczyniali się do uświęcenia świata na kształt zaczynu, od wewnątrz niejako, i w ten sposób przykładem zwłaszcza swego życia promieniując wiarą, nadzieją i miłością ukazywali innym Chrystusa".

16 Por. Konstytucja soborowa „Lumen gentium” n. 32.

17 ,Ex divina institutione, sunt in Ecclesia aliqui christifideles, qui sacra ordinatione ministri sacri constituuntur et alii christifideles, qui et laici nuncupantur": tekst kanonu ustalony na zebraniu Papieskiej Komisji Odnowy Kodeksu Prawa Kanonicznego $\mathrm{w}$ dniach od 24 do 29 września 1979 („Communicationes” 12, 1980 , s. 46$)$.

18 „\$ 1. Christiifdeles laici, qui non peculiari modo publice Deo consecrantur, ratione baptismi quo Christo configurantur atque confirmationis qua in fide roborantur, missionem participant salvificam Ecclesiae, cuius in muneribus exercendis propriam habent partem. § 2. Huic salvificae missioni adlaborant etiam, cum in rebus temporalibus gerendis et muneribus saecularibus exercendis, Christi testimonium reddunt, res nempe temporales secundum Deum ordinantes" (,Communicationes" 12,1980, s. 47$)$. 
Określenie to jest jaśniejsze i lepiej oddaje ducha Soboru Watykańskiego II niż zawarte we wcześniejszym projekcie „Fundamentalnego prawa Kościoła", pochodzącego z 1970 r. ${ }^{19}$ Porównując te określenia, można zauważyć, że zostało pominięte wyrażenie: „którzy nie otrzymali święceń wyższych, ani też nie praktykują życia zakonnego zatwierdzonego przez Kościół”, a na to miejsce wprowadzono słowa: „którzy nie zostali w szczególny sposób publicznie poświęceni Bogu'. Pominięto więc negatywne określenie świeckich, a mianowicie kim nie są, wprowadzając natomiast moment odróżniający ich od duchownych i zakonników. Dalej pominięto stwierdzenie, że wypełnianie posług przez świeckich jest określone i kierowane przez władzę kościelną. Pominięcie to wychodzi na korzyść określenia, gdyż lepiej uwidacznia autonomię świeckich, a o wypadkach, w których świeccy podlegają kierownictwu hierarchii mòżna , powiedzieć gdzie indziej. Wreszcie zupełnie pominięto paragraf trzeci mówiący o współpracy, świeckich z hierarchią, gdyż to zagadnienie łączy się z prawami i obowiązkami świeckich.

Ustalone w 1979 r. określenie świeckich odpowiada soborowej nauce o laikacie, zawartej w konstytucji dogmatycznej „Lumen gentium”, uwzględnia bowiem prawdę o zjednoczeniu z Chrystusem, podkreśla udział w posługach Kościoła, zwraca uwage na specyficzne powołanie świeckich oraz ich aktywną rolę w Kościele i świecie. Można by jeszcze krótko wspomnieć o podstawowej równości hierarchii i świeckich, co jest w projekcie zaznacone na innym miejscu ${ }^{20}$. Wydaje się także, że w zdaniu: „Huic salvicae missioni adlaborant etiam”, słowo ,etiam” można by zastąpić słowem ,in primis”, gdyż świeccy spełniają zbawcze posłannictwo przede wszystkim przez realizację swojego świeckiego powołania.

\section{UDZIAE SWIECKICH W POTROJNEJ MISJI KOSCIOEA}

Projekt „Fundamentalnego prawa Kościoła” omawiając potrójną misję Kościoła, uwżględnia także uczestnicwo w niej ludzi świeckich.

19 Kan. 30, § 1. „Christifideles laici, qui neque ardine sacro sunt insigniti neque statum religiosum ab Ecclesia sancitum susceperunt, ratione baptismatis quo Christo configurantur atque confirmationis qua in fide roborantur, missionem participant salvicam Ecclesiae, cuius in muneribus exercendis propriam habent partem, ab ecclesiastica auctoritate uoque pressius determinandam et ab eadem moderandam. $\S 2$. Praesertim in rebus temporalibus gerendis et muneribus saecularibus exercendis, Christi testimonium reddunt, res temporales secundum Deum ordinantes. § 3. Habiles iidem sunt qui in rebus Ecclesiae a sacris pastoribus consulantur ad normam iuris et ab munera ecclesiastica suae conditioni congrua ab eisdem deputentur'.

20 ,Inter Christifidels omnes, ex eorum in Christo regeneratione vera viget sequalitas quoad dignitatem et quoad actionem qua cuncti, unusquisque quidem secundum propriam conditionem propriumque munus, ad aedificationem Corporis cooperantur”, kan. 9. („Communicationes” 12, 1980, s. 36). 
We wcześniejszym projekcie (1970 r.) wymienia się uczestników potrójnej misji Kościoła w naștępującej kolejności: biskupi, kapłani i wierni, bez szczegółowego wyróżnienia świeckich ${ }^{21}$. Takie rozwiązanie nie było szczęśliwe, gdyż $1^{\circ}$ sugerowało jak gdyby kapłani i biskupi nie należeli do wiernych, $2^{\circ}$ nie uwzględniało wyraźnie świeckich, którzy zgodnie z nauką konstytucji dogmatycznej „Lumen gentium” n. 31, na swój sposób, są uczestnikami kapłańskiego, prorockiego i królewskiego urzędu Chrystusa. Dopiero późniejszy projekt „Prawa fundamentalnego” wyraźnie wymienia świeckich jako uczestników kapłańskiego, prorockiego i królewskiego posłannictwa Chrystusa i Kościoła ${ }^{22}$.

\section{Udział świeckich w funkcji nauczania}

Schemat „Fundamentalnego prawa Kościoła” (1970 r.) podkreśla uczestnictwo całego Ludu Bożego, a więc i świeckich w prorockiej misji Chrystusa, przede wszystkim przez świadectwo życia nacechowanego wiarą i miłością, ale także przez głoszenie prawdy Chrystusowej. Uzasadnieniem tej postawy jest namaszczenie Duchạ Swiętego, dzięki któremu ogół wiernych nie może zbłądzić w wierze i ujawnia nadprzyrodzony zmysł wiary, gdy ,,poczynając od biskupa aż do ostatniego z wiernych świeckich ukazuje swą powszechną w sprawach wiary i obyczajów" (kan. 55) ${ }^{23}$.

Nauka zawarta w tym kanonie projektu jest właściwie powtórzeniem n. 12 konstytucji „Lumen gentium” i potwierdza specyficzny udział świeckich w posłudze nauczania.

Projekt „Fundamentalnego prawa Kościoła” wymieniając osoby, na których spoczywa troska o głoszenie Słowa Bożego, a więc papieża, biskupów, kapłanów, diakonów, dodaje, że w wypełnianiu tego obowiązku biskupi mają korzystać z pomocy zakonników oraz odpowiednich osób świeckich, mężczyzn i kobiet. Świeccy mogą to czynić po uzyskaniu upoważnienia od kompetentnej władzy kościelnej ${ }^{24}$.

Szczegółowe rozpracowanie wypełniania posługi głoszenia Słowa Bożego znajdujemy w pracach konsultorów „O nauczycielskim urzędzie Kościoła”. Mówiąc o posłudze Słowa Bożego, projekt wymienia świeckich jako uczestniczących w spełnianiu tej posługi ${ }^{25}$. Kiedy jednak przechodzi

21 Por. Schemat „Fundamentalnego prawa Kościota”, 1970, kan. 53.

22 ,Christifideles laici, quippe qui baptismo quo Christo incorporantur et confirmatione qua in fide roborantur de munere Christi sacerdotali prophetico et regali suo modo participes facti sint, in missione Ecclesiae explenda propriam sibi partem habent”, kkan. 55, § 2, (,Communicationes” 9, 1977, s. 105).

${ }^{23}$ Por. Schemat "Lex Ecclesiae Fundamentalis" (= Schemat LEF), kan. 55, § 1 i 2 .

24 Schemat LEF, 1970, kan. 60, 61, 62.

25 "Communicationes" 7 (1975) s. 151. 
do szczegółowego zagadnienia o głoszeniu Słowa Bożego w czasie świętej liturgii, gdzie Słowo Boże jest jej częścią, jak np. homilia w czasie celebracji eucharystycznej, wówczas stawia zasadę, że nie należy dopuścić świeckich. Może to mieć miejsce tylko w wyjątkowych wypadkach i to za zezwoleniem ordynariusza, po uwzględnieniu przepisów Konferencji Biskupiej ${ }^{26}$.

Schemat „Posługa nauczania w Kościele”, mówiąc ogólnie o posłudze Słowa Bożego, wymienia świeckich jako jej uczestników, natomiast w rozdziale „O przepowiadaniu Słowa Bożego" zaznacza, że upoważnienie do głoszenia Słowa Bożego ordynariusz winien udzielać tylko kapłanom lub diakonom, natomiast świeckich nie należy dopuszczać do przepowiadania $\mathrm{w}$ kościołach, chyba że w pewnych warunkach domaga się tego konieczność, albo w szczególnych okolicznościach będzie to pożyteczne. Należy także uwzględnić postanowienia Konferencji Episkopatu. I tutaj homilia jest zarezerwowana tylko kapłanom i diakonom ${ }^{27}$.

Nieco inaczej ustawia sprawę schemat „O Ludzie Bożym”, który stwierdza, że świeccy mogą przepowiadać Słowo Boże, gdy zachodzi konieczność lub pożytek Kościoła, a brakuje kapłanów i diakonów ${ }^{28}$.

Swieccy zatem na podstawie uczestnictwa w proroczej misji Chrystusa są zdolni, aby przepowiadać Słowo Boże. Dotychczasowy zakaz zabraniający świeckim przepowiadania Słowa Bożego w kościele jest dyscyplinarnym rozporządzeniem Kościoła i może być zniesiony wówczas, gdy tego będzie domagać się potrzeba wspólnoty kościelnej ${ }^{29}$. Wydaje się, że taka potrzeba już zaistniała w wielu regionach świata. Można by więc znieść w prawie powszechnym zakaz głoszenia Słowa Bożego świeckim w kościele, zachowując daleko posuniętą ostrożność przy udzielaniu takich zezwoleń, pozostawiając szczegółowe ustalenia Krajowym Konferencjom Biskupów.

Schemat „Posługa nauczania w Kościele” zẃraca uwagę, że proboszcz, troszcząc się o formację katechetyczną dzieci, młodzieży i dorosłych, winien skorzystać także z pomocy świeckich, a świeccy ze swej strony mają chętnie świadczyć pomoc $\mathrm{w}$ tym zakresie ${ }^{30}$. Schemat ten podkreśla także ważność zadań wychowawczych i wielką odpowiedzialność świeckich, nauczających w szkołach, za formację powierzonych im dzieci i młodzieży ${ }^{31}$.

${ }_{26}$ Tamże, s. 152.

27 Pontificia Commissio Codici Iuris Canonici Recognoscendo, Schema canonum libri III „De Ecclesiae munere docendi”, Typis Polyglottis Vaticanis, 1977, kan. 18 i $19 \S 1$.

${ }_{28}$ Schemat ,De Populo Dei”, kan. 529, § 3.

29 Por. D. Castagna, Czy świeccy moga dziś głosić Stowo Boże?, "Concilium" Międzynarodowy przegląd teologiczny, 1-10 (1968), Poznań-Warszawa 1969, s. 154.

30 Schemat „De Ecclesiae munere docendi”, kan. 28.

${ }^{31}$ Tamże, kan. 48. 
Projekt nowego prawa bardzo mocno akcentuje prawo i obowiązek świeckich do poznania Ewangelii. Wszyscy ochrzczeni są obowiązani żyć zgodnie z Ewangelią, a w razie potrzeby jej bronić, dlatego mają prawo i obowiązek poznać jej zasady ${ }^{32}$. Zobowiązanie to wzrasta wówczas, jeśli świeccy chcą sami głosić naukę,objawioną ${ }^{33}$.

Projekt nowego prawa podejmuje także zagadnienie wykształcenia teologicznego świeckich. Najpierw projekt „Fundamentalnego prawa Kościoła" stwierdza, że poszczególnym wiernym przysłuuje prawo uzyskania wykształcenia $\mathrm{w}$ zakresie dyscyplin teologicznych ${ }^{34}$. Prawo do wykształcenia teologicznego jest wymienione przy wyliczaniu fundamentalnych praw i obowiązków wiernych. Nie można wszakże, jeśli chodzi o wykształcenie teologiczne, jednakowo traktować wszystkich wiernych bowiem dla kapłanów jest ono obowiązkiem, a prawem jest tylko dla świeckich $^{35}$.

Schemat „O Ludzie Bożym” przyznaje świeckim prawo do zdobywania pełniejszej wiedzy teologicznej na kościelnych uniwersytetach i fakultetach. Mogą oni uczęszczać na wykłady i zdobywać stopnie akademickie, jak również otrzymywać od kompetentnej władzy kościelnej misję kanoniczną do wykładania nauk kościelnych ${ }^{36}$.

Schemat „Posługa nauczania w Kościele” posuwa się dalej, zobowiązując władzę kościelną do zatroszczenia się, aby na uniwersytetach katolickich, a nawet - gdzie to jest wskazane i możliwe - również na innych uniwersytetach erygować wydział, albo instytut, ewentualnie katedrę teologii, prowadzące wykłady przystosowane także dla studentów świeckich ${ }^{37}$.

Swieckich dotyczy także zastrzeżenie, że podejmując badania naukowe różnych dyscyplin wiedzy kościelnej, chociaż cieszą się słuszną wolnością potrzebną do rozwoju nauki, zobowiązani są jednak do należnego posłuszeństwa Nauczycielskiemu Urzędowi Kościoła ${ }^{38}$.

\section{Udział świeckich $\mathrm{w}$ funkcji uświęcania}

Projekt „Fundamentalnego prawa Kościoła” z 1970 r., omawiając posługę uświęcania w Kościele, nie wyszczególnia świeckich jako jej uczestników. Stwierdza tylko ogólnie, że wszyscy wierni, konsekrowani na królewskie kapłaństwo przez odrodzenie i namaszczenie Ducha Świętego

32 Por. „Communicationes” 12 (1980) s. 40. Por. Schemat „De Populo Dei”, kan. 527.

33 Tamże, kan. 527, § 1'.

34 Schemat LEF, 1970, kan. 18.

35 Por. W. Góralski, O kartę praw chrześcijanina, „Chrześcijanin w świecie" 12 (1980) $\mathrm{nr} 11-12$, s. 142.

36 Schemat „De Populo Dei”, kan. 527, § 2 i 3.

37 Schemat „De Ecclesiae munere docendi”, kan. $61 \S 1$.

38 Schemat „De Populo Dei”, kan. 22, § 2. 
są wezwani, ażeby przez swoje modlitwy, ofiary, a zwłaszcza uczynki miłości przyczyniać się do zbawienia świata ${ }^{39}$. Późniejszy projekt z 1977 r., wymieniając uczestników posługi uświęcania, uwzględnia także świeckich, którzy swój udział mają zaznaczyć przede wszystkim aktywnym uczestnictwem w obrzędach liturgicznych, a zwłaszcza w celebracji eucharystycznej, jak również modlitwami i spełnianiem uczynków miłości ${ }^{40}$. Szczególnymi środkami uświęcania są święte sakramenty, toteż powinny być szafowane i przyjmowane z najwyższym szacunkiem i starannością ${ }^{41}$. Sakramenty święte należą do podstawowych dóbr Kościoła, których świeccy mają prawo żądać od hierarchii ${ }^{42}$.

Nie ulega wątpliwości, że świeccy swoje uczestnictwo w posłudze uświęcania realizują przede wszystkim przez gorliwe i należyte przyjmowanie sakramentów, na co także zwracano uwagę w dotychczasowym prawie. Wydaje się, że nowością wprowadzoną przez projekt prawa jest zaakcentowanie aktywnej i dynamicznej postawy świeckich.

W pewnych wypadkach świeccy mogą być szafarzami świętych sakramentów. W wypadkach nieo,becności lub przeszkodzenia kapłana albo diakona może chrzcić katechista, a w wypadku konieczności każdy człowiek $^{43}$. Nadzwyczajnym szafarzem komunii świętej, w wyjątkowych sytuacjach, może być świecki ${ }^{44}$. Także nadal aktualna pozostaje nauka o sakramencie małżeństwa, którego szafarzami są sami zawierający małżeństwo. Natomiast projekt nowego prawa wyraźnie stwierdza, że jedynym szafarzem ofiary eucharystycznej jest tylko kapłan, a więc świecki w żadnym wypadku nie może przewodniczyć celebracji eucharystycznej ${ }^{45}$. Podobnie szafarzem sakramentu pokuty i namaszczenia chorych może być tylko kapłan ${ }^{46}$.

Jeśli chodzi o wykonywanie niektórych funkcji liturgicznych, to projekt przyznaje świeckim możliwość ich spełniania. Mężczyźni świeccy, posiadający odpowiedni wiek i przymioty określone przez Konferencję Episkopatu, mogą być poprzez obrzęd liturgiczny ustanawiani do wykonywania na stałe posługi lektora i akolity. Natomiast świeccy, którym

${ }^{39}$ Schemat $L E F, 1970$, kan. 73 , § 2.

40 „In munere sanctificandi explendo propriam sibi partem habent alii quoque qui constituti sunt ministri necnon et christifidels laici, imprimis ministeria, si quae receprint exercendo atque active in liturgicis celebrationibus, in eucharistica praesertim celebratione, suo modo participando, sed et orationibus Deum deprecando atque opera caritatis ordinando et adlimplendo”, kkan. 65, § 4. („Communicationes" 9, 1977, s. 275-276).

${ }^{41}$ Por. Pontificia Codici Iuris Canonici Recognoscendo, Schema documenti pontificii quo disciplina canonica de sacramentis recognoscitur, 1975, kan. 1.

42 Por. „Communicationes” 12 (1980) s. 38.

43 Schemat „De Sacramentis”, kan. 10, § 2.

44 Tamże, kan. 70, § 2.

45 Tamże, kkan. 62, § 1 .

46 Tamże, kan. 135, kan. 182, § 1 . 
nie udzielono posługi i to zarówno mężczyźni, jak i kobiety mogą być czasowo wyznaczeni do spełniania funkcji lektora w czynnościach liturgicznych. Ponadto wszyscy świeccy mogą wypełniać funkcję komentatora czy kantora, a jeśli zachodzi potrzeba mogą przewodniczyć modlitwom liturgicznym ${ }^{47}$. Schemat „O Ludzie Bożym" potwierdza wymienioną już w schemacie „O sakramentach” możliwość w pewnych wypadkach udzielania przez świeckich chrztu świętego i komunii świętej ${ }^{48}$. Warto zwrócić uwagę na wspomniany już stosunek projektu nowego prawa odnośnie do szafarza mszy świętej oraz sakramentu pokuty i namaszczenia chorych, które wyraźnie podkreśla wyłączną zdolność kapłana, niedopuszczając żadnych wyjątków, wbrew sugestiom niektórych autorów ${ }^{49}$.

\section{Udział świeckich w funkcji pasterzowania}

Projekt „Fundamentalnego Prawa Kościoła” z 1970 r. w artykule o funkcji pasterzowania w Kościele stwierdza, że świeccy, którzy przez sakrament chrztu we właściwy sobie sposób, stali się uczestnikami posług Chrystusa, są powołani, aby biskupom świadczyć pomoc w kierowaniu ludem, przez wypełnianie powierzonych im funkcji, które są zdatni wypełniać. Muszą być kompetentni i należycie przygotowani ${ }^{50}$.

W dniach od 23 do 27 lutego 1976 r. zespół specjalny, zajmując się projektem „Fundamentalnego prawa Kościoła”, wszczął dyskusję nad kanonem 75 mówiącym o wykonywaniu posługi rządzenia przez biskupa diecezjalnego. W czasie dyskusji padło pytanie: czy władza ustawodawcza i sądownicza może być powierzona świeckim. Za przyznaniem jej świeckim przytaczano różne racje, mianowicie fakt powierzenia przez motu proprio Pawła VI „Causas matrimoniales” możliwości spełniania przez świeckich funkcji sędziów kościelnych. Następnie powołano się na fakt historyczny, że przez wiele wieków opatki posiadały władzę jurysdykcyjną. Odwołano się także do n. 33 konstytucji dogmatycznej „Lumen gentium”, głoszącego: „Swieccy ponadto zdatni są do tego, aby hierarchia przybierała ich do pomocy w wykonywaniu pewnych zadan kościelnych służących celowi duchowemu". Trudności jednak nie rozwiązano, tylko postanowiono je przedłożyć do rozstrzygnięcia Kongregacji Doktryny Wiary ${ }^{51}$.

47 Por. Schemat „De populo Dei”, kan. 529, § $1-3$.

48 Tamże, kan. 529, \& 3.

49 Por. J. Duss von Werdt, Co może świecki bez kaptana?, „Concilium”. Międzynarodowy przegląd teologiczny, $1-10$ (1968), Poznań-Warszawa, 1969, s. 214-215; por. O. Reegen, Prawa świeckich, tamże, s. 419-420.

so Schemat LEF, kan. 83.

51 „Communicationes" 9 (1977) s. 288. 
Na tej samej sesji zespół specjalny zajmujący się „Fundamentalnym prawem Kościoła" stanął na stanowisku, że świeccy są powołani, aby pomagać biskupom w rządzeniu Ludem Bożym, toteż zgodnie z przepisami prawa mogą otrzymywać różne urzędy ${ }^{52}$. W czasie dyskusji zaznaczono jednak, że kanon ten pozostaje tymczasowo, do chwili rozstrzygnięcia przez Kongregację Doktryny Wiary możliwości powierzenia świeckim władzy jurysdykcyjnej ${ }^{53}$. W dotychczas opublikowanych materiałach Papieskiej Komisji Odnowy Kodeksu Prawa Kanonicznego (,Communicationes” 1980) nie znajdujemy rozstrzygnięcia powyższego problemu.

Do tej sprawy nawiązuje również kanon 96 schematu księgi I „O normach generalnych" z 1977 r., zaznaczając, że zdolność do otrzymania władzy w Kościele posiadają ci, którzy przyjęli święcenia, natomiast ci, którzy ich nie otrzymali (świeccy) mogą ją posiadać w poszczególnych wypadkach, gdy im jej udzieli najwyższa władza w Kościele.

Schemat „O Ludzie Bożym” zdecydowanie stwierdza, że świeccy są zdatni otrzymywać od pasterzy Kościoła urzędy kościelne i funkcje "officia ecclesiastica et munera", jeśli odpowiadają wymogom prawa ${ }^{54}$. Wśród wymienionych funkcji, które mogą być powierzone świeckim, schemat wylicza urząd notariusza kurii ${ }^{55}$.

Dość duże możliwości wysuwa się, jeśli chodzi o pracę świeckich w sądownictwie kościelnym; tak więc świeccy będą mogli spełniać w sądach funkcję sędziów, asesorów, audytorów, a w poszczególnych wypadkach promotorów sprawiedliwości i obrońców węzła ${ }^{56}$. Postawiono jednak wymagania pod adresem świeckich zamierzających spełniać funkcje w sądach. Wszystkie wyżej wymienione funkcje mogą spełniać tylko mężczyźni, oprócz funkcji notariusza ${ }^{57}$.

Ważną rolę świeccy mogą odegrać, podejmując troskę o materialne dobra Kościoła. Projekt z 1973 r. proponował powołanie w każdej diecezji rady d/s gospodarczych, na czele której stoi biskup, a w jej skład wchodzi trzech członków, duchownych lub świeckich, biegłych w sprawach ekonomicznych, mianowanych na okres pięcioletni ${ }^{58}$.

52 „Christifideles laici quoque ratione baptismatis sui vocantur, ut episcopis in populo regendo praestent operam, variaque implere valent officia, quae debita competentia et praestantia, si gaudeant, christifidelibus laicis ad normam iuris committi possunt”, kan. 78. (,Communicationes” 9, 1977, s. 293).

53 Tamże, s. 293.

54 Schemat „De Populo Dei”, kan. 528, § 2.

55 Tamże, kan. 296, § 2.

56 Pontificia Commisio Codici Iuris Canonici Recognoscendo, Schema canonum de modo procedendi pro tutela iurium seu de processibus, Typis Polyglottis Vaticanis, 1976, kan. $20, \S 1$, kan. 23 , kan. 27 , § 2 , kan. $35, \S 1$.

57 Tamże, Praenotanda.

58 Pontificia Commissio Codici Iuris Canonici recognoscendo, de curia dioecesana, „Communicationes” 5 (1973) s. $228-229$. 
Propozycja ta nawiązuje do kan. 1520 Kodeksu Prawa Kanonicznego, który nakazuje ustanowić w diecezji Radę Administracyjną, składająca się z przewodniczącego, którym jest biskup, oraz dwóch lub więcej członków duchownych lub świeckich, biegłych w prawie kościelnym i cywilnym. W ważniejszych sprawach związanych z zarządem majątku kościelnego winien biskup wysłuchać jej zdania.

Schemat „O Ludzie Bożym” określa dokładnie strukturę i zadania Diecezjalnej Rady do spraw ekonomicznych albo krócej Diecezjalnej Rady Administracyjnej. Na jej czele stoi biskup lub jego delegat. $\mathrm{Ma}$ się składać przynajmniej z trzech osób świeckich albo duchownych. Jedna z nich winna być członkiem Rady Kapłańskiej. W ukonstytuowaniu Rady Administracyjnej biskup winien kierować się także wytycznymi Krajowej Konferencji Biskupów ${ }^{59}$.

Schemat „Kościelnego prawa majątkowego” proponuje, aby biskup był zobowiązany wysłuchać zdania Diecezjalnej Rady Administracyjnej przed podjęciem ważniejszych aktów związanych $\mathrm{z}$ zarządzaniem dobrami kościelnymi a nawet uzyskać jej zgodę w wypadkach wyliczonych w prawie powszechnym i prawie fundacyjnym, jak i wówczas kiedy zamierza podjąć nadzwyczajne wydatki ${ }^{60}$.

Dla usprawnienia zarządu dobrami materialnymi biskup winien powołać ekonoma diecezjalnego, po wysłuchaniu zdania Kolegium Konsultorów i Diecezjalnej Rady Administracyjnej: Może nim być zarówno osoba duchowna jak i świecka, kompetentna w sprawach ekonomicznych i odznaczająca się szczególną uczciwością. Zarządcę należy mianować na okres pięcioletni, aby administrował dobrami diecezjalnymi pod kierownictwem biskupa ${ }^{61}$. Wydaje się, że troskę o dobra materialne Kościoła w przeważającej mierze należy powierzyć odpowiednim osobom świeckim, pozostawiając jednak nadrzędne kierownictwo i pewną kontrolę władzy kościelnej.

Swój udział, w posłudze pasterskiej Kościoła, mogą świeccy zaznaczyć także przy tworzeniu prawa zwyczajowego. Prawo zwyczajowe wskazuje na udział całej wspólnoty w kształtowaniu prawa. Wspólnota wiernych uczestniczy w działalności prawotwórczej tworząc zwyczaje zgodne z prawem, ,obok prawa” i przeciwne prawu ${ }^{62}$. Projekt nowego Kodeksu zasadniczo powtarza dotychczasowe przepisy odnoszące się do tworzenia prawa zwyczajowego, jedynie tylko obniża okres wymagany

59 Schemat „De Populo Dei”, kan. 306 i 307.

60 Pontificia Commissio Codici Iuris Canonici Recognoscendo, Schema canonum libri V „De iure patrimoniali Ecclesiae”, Typis Polyglottis Vaticanis 1977, kan. 21. 61 Schemat „De Populo Dei”, kan. 308.

62 R. Sobański, Kościót, prawo, zbawienie, Katowice, 1979, s. 308-311. 
do zadawnienia do lat dwudziestu oraz przy zwyczajach przeciwnych prawu wymaga zamiaru zobowiązania się ze strony społeczności ${ }^{63}$.

Projekt fundamentalnego prawa Kościoła zaznacza, że w całym Kościele obowiązują zwyczaje wprowadzone przez wiernych i zatwierdzone przez władzę kościelną ${ }^{64}$.

\section{PRAWA I OBOWIĄZKI SWWIECKICH}

Zostaną tutaj omówione tylko prawa i obowiązki świeckich, które są im właściwe. Jednak nie da się przedstawić praw i obowiązków świeckich $\mathrm{w}$ zupełnej izolacji od praw i obowiązków chrześcijanina. Toteż zwrócimy uwagę także na niektóre prawa i obowiązki wspólne wszystkim ochrzczonym, ale których realizacja przez świeckich posiada swoisty charakter, np. wszyscy ochrzczeni mają prawo i obowiązek działalności apostolskiej, inaczej jednak kształtuje się działalność apostolska świeckich, inaczej zaś duchownych czy zakonników.

1. Prawa i obowiązki wynikające z przynależności do wspólnoty kościelnej

Z nauki soborowej o Ludzie Bożym wynika, że świeccy są pełnoprawnymi i wartościowymi członkami wspólnoty Ludu Bożego i z tego tytułu mają pewne prawa i obowiązki. Podstawowy wśród nich to zaangażowanie się w działalność apostolską.

Schemat „O Ludzie Bożym” w rozdziale pt.: „Obowiązki i prawa świẹckich" stwierdza, że świeccy są na równi ze wszystkimi wiernymi przeznaczeni przez Boga do apostolstwa, tj. do uczestnictwa w zbawczej misji Kościoła. Mają więc troszczyć się o to, aby orędzie zbawcze zostało poznane i przyjęte przez wszystkich ludzi na całej ziemi. Ten obowiązek wiąże ich jeszcze bardziej w tych okolicznościach, w których ludzie jedynie za ich pośrednictwem mogą usłyszeć Ewangelię i poznać Chrystusa ${ }^{65}$. Wszyscy wierni, a więc także świeccy, w działalności apostolskiej mogą rozwijać własne inicjatywy, mogą ją prowadzić na własną rękę niemniej jednak swoich własnych koncepcji nie mogą nazywać katolickimi, jeśli uprzednio nie otrzymają zatwierdzenia kompetentnej władzy kościelnej ${ }^{66}$.

63 Pontificia Commisio Codici Iuris Canonici Recognoscendo, De recognoscendis normis generalibus Codicis Iuris Canonici, "Communicationes" 3 (1971) s. 86-87; Schema canonum libri I „De normis generalibus”, Typis Polyglottis Vaticanis 1977, kan. $24-29$.

${ }^{64}$ Schemat LEF, kan. 77, § 2, „Communicationes” 9 (1977) s. 281-282.

65 Schemat „De Populo Dei”, kan. 524, \& 1.

66 Por. „Communicationes" 12 (1980) s. 89. 
W działalności apostolskiej, właściwej świeckim, przysługuje im wolność, jednak w ocenie wszystkich spraw winni oni zachować prawo Boże, zgodnie $\mathrm{z}$ tym, jak jest ono przedstawione przez Nauczycielski Urząd Kościoła, natomiast w sprawach wątpliwych nie mogą zastawiać się autorytetem Kościoła ${ }^{67}$.

Będąc wszczepieni w Kościół Chrystusowy, świeccy są zobowiązani tak postępować, aby zawsze zachować wspólnotę z tymże Kościołem, wypełniając wobec niego wszystkie obowiązki, jak również, stosownie do swoich warunków i kompetencji, podejmować działalność zmierzającą do jedności między wszystkimi chrześcijanami ${ }^{68}$.

Swoją działalność apostolską mogą świeccy realizować nie tylko pojedynczo, ale także wspólnie zrżeszając się w stowarzyszenia. Projekt prawa konstytucyjnego Kościoła zapewnia świeckim możliwość swobodnego zakładania stowarzyszeń i kierowania nimi w celu wykonywania dzieł miłosierdzia i pobożności ${ }^{69}$. Swieccy winni bardzo doceniać stowarzyszenia ustanowione dla osiągnięcia celów duchowych, takich jak pogłębienie życia chrześcijańskiego, spotęgowania kultu publicznego, pogłębienia chrześcijańskiej wiedzy, podjęcia dzieł ewangelizacyjnych, przepojenia duchem chrześcijańskim porządku doczesnego, prowadzenia dzieł pobożności lub miłości. Świeccy winni się starać, aby podejmowana przez nich działalność $w$ stowarzyszeniach stanowiła pomoc dla duchowieństwa w wykonywaniu różnych funkcji duszpasterskich. Pożądana też jest współpraca między poszczególnymi stowarzyszeniami ${ }^{70}$.

Mając na uwadze fakt, że wspólnota Kościoła posiada charakter bosko-ludzki i element ludzki niejednokrotnie odzywa się w niej w sposób niewłaściwy, zachodzi konieczność prawnego zabezpieczenia i prawnej obrony uprawnień świeckich. Czyni to projekt „Fundamentalnego prawa Kościoła" zapewniając im zabezpieczenie i obronę uprawnień przez kompetentne forum kościelne i to zarówno na drodze sądowej jak i administracyjnej. Mogą być też sądzeni tylko przez kompetentną władzę zgodnie z przepisami prawa ${ }^{71}$.

Prawie te same dyspozycje powtarza schemat „O Ludzie Bożym” w kanonach 34, 35 i 36 . Dlatego też zespół konsultorów dyskutujący nad tymi kanonami w dniu 20 października 1979 r. postanowił je usunąć ze schematu $\mathrm{w}$ ten sposób, by te przepisy, które nie są umieszczone w schemacie „Fundamentalnego prawa Kościoła” umieścić w schemacie „O postępowaniu administracyjnym" "72.

67 Por. Schemat „De Populo Dei”, kan. 525.

68 Tamże, kan. 19 , § 1, kan. 20.

${ }^{69}$ Por. „Communicatones" 12 (1980) s. 89.

69 Tamże.

70 Por. Schemat „De Populo Dei”, kan. 39, § 1, kan. 532.

71 ,Communicationes" 12 (1980) s. 42.

72 Tamże, s. 86-90. 
Działalność Kościoła wymaga pewnej ilości dóbr materialnych, które winni na rzecz wspólnoty kościelnej świadczyć wszyscy wierni. Chociaż projekt prawa używa określenia wierni, to nie ulega wątpliwości, że chodzi tu o świeckich. Wskazuje na to stwierdzenie, że obowiązek zależy od możliwości indywidualnych i warunków rodzinnych ${ }^{73}$.

Projekt „Kościelnego prawa fundamentalnego" zobowiązuje wiernych do świadczenia środków potrzebnych do kultu Bożego, do spełniania dzieł apostolatu i miłosierdzia i na utrzymanie kleru ${ }^{74}$. Ten sam obowiązek powtarza schemat „O Ludzie Bożym” w kanonie 29. W czasie dyskusji nad tymże schematem w dniu 19 października 1979 r. konsultorzy uznali, że obowiązek świadczeń na rzecz wspólnoty kościelnej jest wystarczająco omówiony w schemacie „Fundamentalnego prawa Kościoła” i w schemacie „Prawa majątkowego Kościoła”. Stąd nie ma potrzeby powtarzania go w schemacie „O Ludzie Bożym”. Dlatego kan. 29 tegoż schematu zostaje zniesiony ${ }^{75}$.

Projekt prawa zwraca także uwagę na to, że świeccy zaangażowani w sposób szczególny w pracę dla Kościoła mają prawo do słusznego wynagrodzenia, dzięki któremu mogliby zaradzić potrzebom własnym i rodziny. Mają też prawo do ubezpieczenia i zabezpieczenia społecznego oraz do ubezpieczenia zdrowotnego ${ }^{76}$.

\section{Prawa i obowiązki wypływające z zasady współdziałania hierarchii i laikatu}

Sobór Watykański II bardzo mocno podkreślił konieczność współdziałania hierarchii z laikatem. Kościół jest niejako sakramentem czyli znakiem i narzędziem wewnętrznego zjednoczenia z Bogiem i jedności całego rodzaju ludzkiego ${ }^{77}$. Kościół nie byłby znakiem jedności całego rodzaju ludzkiego, gdyby w nim samym nie było jedności i doskonałej współpracy hierarchii i laikatu. Nic przeto dziwnego, że sobór naucza: „Kościół nie jest naprawdę założony, nie żyje w pełni, ani też nie jest doskonałym znakiem Chrystusa wśród ludzi, jeśli wraz z hierarchią nie istnieje i nie pracuje autentyczny laikat" "r8.

Prawdę tę próbuje ując w dyspozycję prawną projekt nowego prawa. Schemat „Fundamentalnego prawa Kościoła” z 1970 r. przyznaje wiernym prawo do przedstawiania pasterzom swych potrzeb zwłaszcza duchowych oraz własnych życzeń. Także stosownie do posiadanej wie-

73 Por. Schemat „De Populo Dei”, kan. 29.

74 Schemat LEF, kan. 25; "Communicationes" 12 (1980) s. 42 (kan. 23).

75 Por. Tamże, s. 85.

76 Schemat „De Populo Dei”, kan. 530.

77 Konstytucja soborowa „Lumen gentium”, n. 1.

78 Dekret soborowy „Ad gentes divinitus”, n. 21, 1. 
dzy, kompetencji i autorytetu przysługuje im prawo, a niekiedy nawet obowiązek przedstawienia pasterzom swojego zdania w sprawach dotyczących dobra Kościoła oraz zachowując integralność wiary i biorąc pod uwagę wspólny pożytek a także godność osoby, podawania tego do wiadomości wiernych. Mają zaś to czynić - tam gdzie to jest aktualne za pośrednictwem instytucji powołanych do tego celu przez Kościół ${ }^{79}$.

Tę samą myśl, w sposób skrócony, przedstawia późniejszy projekt „Fundamentalnego prawa Kościoła”, ustalony na zebraniu we wrześniu 1979 r., pomijając wzmiankę o instytucjach powołanych do tego celu przez Kościół ${ }^{80}$.

Podobnie o prawie i obowiązku wypowiadania swojej opinii i przedstawiania potrzeb i życzeń przez wiernych pisze schemat „O Ludzie Bożym" w rozdziale „O prawach i obowiązkach wszystkich wiernych" ${ }^{81}$. Tenże schemat w rozdziale „O obowiązkach i prawach wiernych świeckich" krótko stwierdza, że świeccy odznaczający się odpowiednią wiedzą, roztropnością i uczciwością są zdolni do tego, by pasterze Kościoła wysłuchiwali ich jako biegłych i doradców ${ }^{82}$. Warto zaznaczyć, że stwierdzenie o prawie i obowiązku wiernych do wypowiadania życzeń i zabierania głosu w sprawach Kościoła zawarte w schemacie „Fundamentalnego prawa Kościoła” jak i w schemacie „O Ludzie Bożym” jest zaczerpnięte z Konstytucji dogmatycznej ,Lumen gentium” n. 37 z rozdziału ,O świeckich”. A więc przede wszystkim odnosi się do świeckich, chociaż Konstytucja także wzmiankuje o wszystkich wiernych ,,́́wieccy, tak jak wszyscy wierni" toteż projekt zawarty zarówno w schemacie „Prawa fundamentalnego Kościoła”, jak i w schemacie „O Ludzie Bożym” budzi pewne zastrzeżenia. Wydaje się, że w schemacie „Fundamentalnego prawa Kościoła" winna być ogólna norma o prawie i obowiązku wszystkich wiernych do przedstawiania potrzeb i wyrażania opinii, szczegółowa zaś norma dotycząca świeckich oparta o n. 37 Konstytucji „Lumen gentium" winna się znajdować w schemacie „O Ludzie Bożym", w rozdziale o świeckich. Natomiast nie widać żadnej racji, aby ta norma była powtarzana drugi raz w schemacie „O Ludzie Bożym" w rozdziale o prawach i obowiązkach wiernych.

Swieccy mogą zabierać głos w sprawach Kościoła, wyrażać swoje opi-

79 Schemat LEF, 1970, kan. 13, § 2 i 3.

80 „§ 2 Christifidelibus integrum est, ut necessitates suas, praesertim spirituales, et optata sua Ecclesiae pastoribus patefaciant. § 3. Pro scientia, competentia et praestantia, quibus pollent ipsis, est ius, immo et aliquando officium, ut sententiam suam de his, quae ad bonum Ecclesiae pertiment, sacris pastoribus manifestent atque salva fidei morumque integritate et attentis communi utilitate necnon personarum dignitate, chistifidelibus notam faciant" (,Communicationes" 12 , 1980, s. $37-38)$.

${ }^{81}$ Schemat ,De Populo Dei”, kan. 28.

${ }^{82}$ Tamże, kan. 528, § 1. 
nie, służyć radami w różny sposób. Celem ułatwienia im tego po Soborze Watykańskim II zostały ustanowione różne nowe instytucje doradcze, których świeccy mają udział prawnie zapewniony, jak również do już istniejących wprowadzono świeckich. Projekt nowego Kodeksu zajmuje się $\mathrm{m}$. in. radami duszpasterskimi i synodami.

W poszczególnych diecezjach należy ustanowić Diecezjalną Radę Duszpasterską, o ile doradzają to potrzeby duszpasterskie. Radą kieruje biskup. Składa się ona $\mathrm{z}$ duchownych zakonników i świeckich, z tym, że większość mają stanowić świeccy. Należy ich tak dobrać, by skład Rady był rzeczywistym odzwierciedleniem Ludu Bożego diecezji. Diecezjalna Rada Duszpasterska posiada tylko głos doradczy ${ }^{83}$.

Projekt nowego kodeksu pragnie ożywić działalność Synodów partykularnych, które dzielą się na regionalne i prowincjonalne ${ }^{84}$. W Synodach partykularnych mogą wziąc udział świeccy, z tym że przysługuje im tylko głos doradczy ${ }^{85}$.

Projekt nowego prawa stara się przywrócić szczególną rolę synodom diecezjalnym, które mają przybrać charakter duszpasterski. W projekcie kilka razy nawiązuje się do udziału świeckich w Synodzie diecezjalnym. $\mathrm{Na}$ synod ten powinni być wezwani i mają obowiązek przybyć świeccy zarówno mężczyźni, jak i kobiety, jako delegaci Diecezjalnej Rady Duszpasterskiej wybrani przez nią i w sposób określony przez biskupa, a tam, gdzie nie ma rady, przez niego wyznaczeni ${ }^{86}$. Oprócz tych, biskup może wezwać także innych świeckich ${ }^{87}$. Przed odbyciem się synodu diecezjalnego biskup winien ustanowić jedną lub kilka komisji celem przygotowania przedmiotu obrad synodalnych. W skład komisji mogą wejść świeccy ${ }^{88}$.

Swieccy są zobowiązani do posłuszeństwa i szacunku wobec hierarchii. Mówi o tym dwukrotnie projekt „Fundamentalnego prawa Kościoła" ${ }^{89}$ i trzykrotnie schemat „O Ludzie Bożym" ${ }^{90}$. Jest to zapewne przesada, zresztą sami konsultorzy na zebraniu 18 i 19 października 1979 r. uznali za stosowne, aby znieść normy mówiące o posłuszeństwie i szacunku dla hierarchii znajdujące się w schemacie „O Ludzie Bożym" ${ }^{91}$.

83 Por. tamże, kan. $326-329$.

84 Tamże, kan. 188, 189.

85 Tamże, kan. $193, \S 4$ i 5 .

${ }^{86}$ Tamże, kan. 273 , § 1 .

87 Tamże, kan. 273 , § 2 .

88 Tamże, kan. 275.

89 "Communicationes" 12 (1980) s. 37, kan. 12 , § 1 oraz kan. 18; tamże, s. 40.

90 Schemat ,De Populo Dei”, kan. 18, § 2, kan. 22, § 2, kan. 23.

91 , „Communicationes" 12 (1980) s. $78-83$. 
3. Prawa i obowiązki wynikające ze szczególnego powołania świeckich

Jak już wspomniano, powołaniem świeckich jest szerzenie królestwa Bożego przez zajmowanie się sprawami świeckimi i kierowanie nimi po myśli Bożej. Projekt „Fundamentalnego prawa Kościoła” dwukrotnie podkreśla, że świeccy przez zajmowanie się sprawami doczesnymi i wypełnianie funkcji świeckich mają dawać świadectwo Chrystusowi układając sprawy ziemskie zgodnie $\mathrm{z}$ wolą Bożą; pierwszy raz w kan. 30, §2, w którym jest podane określenie świeckich; drugi raz w kan. 85, §2, który mówi o uznawaniu przez Kościół autonomii spraw doczesnych i porządku społecznego ${ }^{92}$.

Późniejszy projekt „Fundamentalnego prawa Kościoła” te same tezy powtarza bez zasadniczej zmiany, jedynie krócej i bardziej precyzyjnie ${ }^{93}$. Schemat „O Ludzie Bożym” w rozdziale „O obowiązkach i prawach wiernych świeckich" zasadniczo powtarza to samo ${ }^{94}$.

Poza ogólnymi stwierdzeniami nie znajdujemy w projekcie nowego prawa wyliczenia poszczególnych funkcji świeckich, przez które mają oni dawać świadectwo Chrystusowi i przemieniać świat zgodnie z wolą Bożą. Funkcje te natomiast wyliczają dokumenty Soboru Watykańskiego II. Są one następujące: wykonywanie pracy zawodowej, udział w życiu politycznym, działalność kulturalna i działalność gospodarczo-społeczna. Swieccy przez wykonywanie pracy zawodowej mają doskonalić porządek naturalny i realizować posłannictwo Kościoła w świecie. Są zobowiązani rozwijać kwalifikacje zawodowe ${ }^{95}$.

Ważną dziedziną działalności świeckich jest aktywny udział w życiu politycznym. Chociaż wspólnota Ludu Bożego nie ma charakteru politycznego, to jednak Kościół uznaje za godną pochwały pracę tych, którzy służą ludowi podejmując się działalności politycznejj, biorą czynny udział w życiu wspólnoty politycznej dla dobra wszystkich jej członków ${ }^{96}$.

Bardzo szeroko konstytucja duszpasterska omawia udział świeckich w działalności kulturalnej. Jest obowiązkiem chrześcijan zabiegać o rozwój kultury osobistej i społecznej odpowiadającej godności osoby ludzkiej. Wierni winni wykazywać troskę o zgodność kultury z obyczajami chrześcijańskimi. Przedmiotem szczególnej troski winno być upowszech-

92 Schemat LEF, 1970.

93 Por. "Communicationes" 9 (1977) s. 98 i 99 ; tamże, 12 (1980) s. 47.

94 Por, Schemat „De Populo Dei”, kan. 524, § 2 i 525.

95 Por. Dekret soborowy „Apostolicam actuositatem”, n. 4.

96 Por. Konstytucja soborowa "Gaudium et spes”, n. 75. 
nianie kultury. Zwrócić trzeba także uwagę na literaturę i sztukę, które mają wielkie znaczenie dla życia Kościoła ${ }^{97}$.

Wśród zadań świeckich bardzo dużo miejsca dokumenty soborowe poświęcają działalności gospodarczo-społecznej, bowiem w tej dziedzinie przedstawia się świeckim szeroki program, a więc działalność na rzecz sprawiedliwości społecznej, wykonywanie dzieł miłosierdzia, popieranie solidarności międzyludzkiej, pokoju i praw człowieka ${ }^{98}$. Kościół chcąc podkreślić niesłychaną wartość i ważność działalności społecznej powołał specjalne instytucje: Papieską Komisję „Iustitia et Pax” i Krajowe Komisje „Iustitia et Pax” zajmujące się problematyką społeczno-gospodarczą. W instytucjach tych główną rolę powierzono świeckim ${ }^{99}$.

Wydaje się, że cztery wspomniane funkcje świeckich, mianowicie: działalność zawodowa, polityczna, kulturalna i społeczna winny być wyliczone w tej części nowego Kodeksu, która jest poświęcona świeckim. Również winny być określone warunki i okoliczności, w jakich mają być one wykonywane.

\section{Prawa i obowiązki wynikające z życia w rodzinie}

Podstawą rodizny jest małżeństwo chrześcijańskie, z którego ono się wywodzi. W rodzinie rodzą się nowi obywatele społeczności ludzkiej, którzy następnie przez chrzest stają się synami Bożymi, aby Lud Boży trwał na zawsze. Rodzina chrześcijańska ma być niejako domowym kościołem ${ }^{100}$.

Projekt „Fundamentalnego prawa Kościoła” z 1970 r. przytacza podstawowe prawdy o sakramencie małżenstwa w kan. 72: „W sakramencie małżeństwa małżonkowie chrześcijańscy wyrażają tajemnicę jedności i płodnej miłości między Chrystusem i Kościołem; oraz uczestnicząc w niej są wzmacniani duchem Chrystusa i jakby konsekrowani, aby wspomagać się wzajemnie w małżeńskim współżyciu, przyjęciu i wychowaniu potomstwa, jak również wspólnym uświęcaniu. Łącząc się $\mathrm{w}$ ten sposób między sobą realizują chwałę Bożą. § 2. Sakrament małżeństwa przyjmują osoby ochrzczone, które nawiązując między sobą nierozerwalną wspólnotę małżeńskiego życia, oddając się sobie nawzajem i przyjmując, przez nieodwołalną zgodę, wyrażoną w sposób określony prze7,4 .

${ }_{97}$ Por. tamże, n. 53-62; por. Dekret soborowy „Apostolicam actuositatem”, n.

98 Por. Dekret soborowy „Apostolicam actuositatem”, n. 7, 4, n. 8, 4, n. 14; por. „Gaudium et spes”, n. 65, n. 41, n. 42. $27-28$.

99 Pawel VI, Motu proprio „Catholicam Christi Ecclesiam”: AAS 59 (1967) s.

100 Por. Konstytucja dogmatyczna „Lumen gentium”, n. 11, 2. 
pisami kościelnymi do ważnego zawarcia związku małżeńskiego" ${ }^{101}$. Kanon ten, będący powtórzeniem nauki soborowej zawartej w konstytucji „Lumen gentium” n. 11, 2 oraz w konstytucji „Gaudium et spes” n. 48, 1 zostaje później skreślony i nie spotykamy go w następnym projekcie „Fundamentalnego prawa Kościoła” ${ }^{102}$. Byłoby jednak wskazane, żeby treść tego kanonu znalazła się w prawie sakramentalnym. Projekt prawa sakramentalnego ogromną uwagę przywiązuje do sakramentu małżeństwa, otaczając go pieczołowicie przepisami mającymi na uwadze ważne i owocne udzielanie i przyjmowanie tego sakramentu.

W projekcie nowego prawa znajdujemy odbicie wskazań soborowych dotyczących wychowania dzieci w rodzinie. Schemat „Fundamentalnego prawa Kościoła" przyznaje, w pierwszym rzędzie prawo i obowiązek wychowania, rodzicom, którzy dali życie dzieciom. Rodzice mają być pierwszymi i głównymi wychowawcami, do nich na pierwszym miejscu należy troska o wychowanie dzieci ${ }^{103}$. Ten sam schemat po raz drugi mówi o rodzicach jako pierwszych i głównych wychowawcach w rozdziale 3 „O Kościele i społeczności ludzkiej” ${ }^{104}$.

Sprawę wychowania dzieci przez rodziców omawia także schemat „Posługa nauczania w Kościele" w tytule trzecim „O wychowaniu chrześcijańskim". Powtórzono tutaj tezę, że rodzice są głównymi i pierwszymi wychowawcami, którzy mają stworzyć atmoferę rodzinną przepojoną miłością i szacunkiem dla Boga i ludzi, aby sprzyjała całemu osobistemu i społecznemu wychowaniu dzieci. W wypełnianiu zadań wychowawczych chrześcijańscy rodzice mają prawo i obowiązek skorzystać z pomocy innych, którzy mają przyczynić się do ich formacji. Mają także prawo do otrzymania tych pomocy, które są potrzebne do tego, by formacja chrześcijańska postępowała harmonijnie z formacją świecką. Rodzice winni doceniać bardzo tę pomoc, jaką otrzymują w wychowaniu od szkoły. Rodzice i nauczyciele mający jako wspólny cel - dobro dzieci - winni ściśle ze sobą współpracować. W wybórze szkoły rodzice winni się cieszyć prawdziwą wolnością. Winni oni także o ile jest to możliwe, powierzyć swoje dzieci szkołom uznanym za katolickie, a gdy ich brak takim, w których zabezpieczone jest kształcenie w zakresie nauki chrześcijańskiej. Gdyby i to było niemożliwe, obowiązani są sami zatroszczyć się o to, by ich dzieci poza szkołą otrzymywały konieczne wychowanie chrześcijańskie, zgodnie z normami wydanymi przez kompetentną władzę kościelną ${ }^{105}$.

101 Schemat LEF, 1970.

102 Por. "Communicationes" 9 (1977) s. 275-279.

103 Schemat LEF, 1970, kan. 24, § 1.

104 Tamże, kan. 91.

105 Schemat „De Ecclesiae munere docendi”, kan. 43-50.

42 - Analecta Cracoviensia 
W schemacie „O Ludzie Bożym” w rozdziale „O obowiązkach i prawach wiernych świeckich" nie spotykamy żadnej wzmianki o prawie i obowiązku rodziców do wychowania, a przecież prawo to i obowiązek jest jak najbardziej właściwe świeckim. Wprawdzie o prawie tym mówi schemat „Fundamentalnego prawa Kościoła” i schemat „Posługa nauczania w Kościele", ale chyba tutaj także winno ono być wspomniane.

\section{ZAKONCZENIE}

Wydaje się, że bogata w treści nauka Soboru Watykańskiego II o laikacie nie znalazła pełnego odzwierciedlenia w normach projektu nowego prawa. Autorzy projektu stanęli przed trudnym zagadnieniem uporządkowania obfitego materiału, w zdecydowanej większości teologicznego i przetransponowania go na zwięzły i precyzyjny język prawny. Problematyka dotycząca świeckich była jeszcze o tyle trudniejsza, że brakowało dotychczas wypracowanych wzorów. Mimo to trzeba przyznać, że zdecydowana większość soborowej nauki o świeckich znajduje się w projekcie nowego prawa. Co więcej można zauważyć, że w miarę postępu prac Papieskiej Komisji Odnowy Kodeksu Prawa Kanonicznego poszczególne zagadnienia są ujmowane lepiej i w sposób dojrzalszy.

Nie ulega wątpliwości, zresztą Sobór to bardzo mocno podkreśla, że świeccy należą do Ludu Bożego, że istnieje podstawowa równość wszystkich ochrzczonych. Ta podstawowa równość nie przeszkadza istnieniu różnic co do funkcji zadań spełnianych we wspólnocie Kościoła. Stąd świeckim przysługuje właściwa pozycja prawna w Kościele. Ta sprawa została nie najlepiej przedstawiona w projekcie nowego prawa. Mianowicie w schemacie „Fundamentalnego prawa Kościoła” jest część jednego artykułu pt.: „Podstawowe prawa i obowiązki wiernych”. O podqbnym tytule jest rozdział w schemacie „O Ludzie Bożym”: „O obowiązkach i prawach wszystkich wiernych", w tymże schemacie znajduje się także rozdział: „O obowiązkach i prawach wiernych świeckich”.

Zestawiając te trzy miejsca można dostrzec niepotrzebne powtórzènia. I tak rozdział „O obowiązkach i prawach wszystkich "wiernych” znajdujący się w schemacie „O Ludzie Bożym” jest w wielu wypadkach powtórzeniem schematu „Fundamentalnego prawa Kościoła”. Zauważyli to zresztą sami konsultorzy prowadząc dyskusję w 1979 r. nad schematem "O Ludzie Bożym”.

Wydaje się, że rozdział: „O fundamentalnych prawach i obowiązkach wszystkich ochrzczonych” powinien znaleźć się w „Fundamentalnym prawie Kościoła”, natomiast rozdział „O wspólnych prawach i obowiązkach wszystkich ochrzczonych" winien być zniesiony w schemacie „O Ludzie 
Bożym”. Niemniej jednak w „Fundamentalnym prawie Kościoła” mogłyby być wymienione tylko same fundamentalne prawa i obowiązki wier.nych, ponieważ - jak się wydaje - prawa i obowiązki wyliczone w dostępnych wszystkim schematach „Fundamentalnego prawa Kościoła”, nie zawsze mają charakter podstawowy. Podając taki katalog w niektórych wypadkach, powstaną trudności i będzie dyskusyjna fụndamentalność takiego czy innego prawa lub obowiązku.

Natomiast w schemacie „O Ludzie Bożym” winien znaleźć się rozdział „Prawa i obowiązki właściwe duchownym”, oraz rozdział „Prawa i obowiązki właściwe świeckim". Można przypuszczać, że proponowane rozgraniczenie między fundamentalnymi prawami i obowiązkami wszystkich ochrzczonych, a prawami i obowiązkami właściwymi świeckim nie będzie doskonałe, że zaistnieją pewne powtórzenia i powiązania, które niekiedy są konieczne.

Prace Papieskiej Komisji trwają nadal intensywnie. Można się spodziewać, że pozycja prawna świeckich, jaką przedstawi nowy Kodeks i „Fundamentalne prawo Kościoła” będzie bardziej odpowiadać wskazaniom Soboru Watykańskiego II i potrzebom Kościoła we współczesnym świecie.

\section{DIE STELLUNG DER LAIEN NACH DEN ARBEITEN DER PÄPSTLICHEN KOMISSION FÚR DIE REVISION DES CIC}

\section{$\mathrm{Zus}$ ammenfassung}

Die Päpstliche Kommission für die Revision des CIC. wurde während des II Vatikanischen Konzils am 28. Mänz 1963. einge setzt. Unter vielen anderen Fragen beschäftigte sie sich auch mit der Problematik der Laien. Um die rechtliche Stellung der Laien in der Kirche zu bestimmen, griff sie zur inhaltsreichen Lehre des Konzils von den Laien. Die im Projekt des neuen Rechtes gefasste Bezeichnung der Laien den Konzilsdokumenten entnommen. Es wird hier von der bisherigen, negativen und statischen Bestimmung der Laien abgesehen, man gibt eine neue, positive und dynamische, welche die besondere Berufung der Laien berückisichtigt.

Die rechtliche Position der Laien gestaltet sich auf Grund ihrer Anteilnahme an der dreifachen Sendung Christi und der Kirche. Die Laien haben, auf eine ihnen eigene Weise, Anteil an der prophetischen, priesterlichen und pastoralen Sendung der Kirche. Sie haben das Recht zur Ausübung bestimmter Tätigkeiten, das ihnen nicht entzogen werden kann, nur die kirchliche Behörde ist berechtigt, die Bedingungen dieses Wirkens zu bestimmen.

Die Laien haben gewisse, ihnen zustehende eigene Rechte und Pflichten. Diese Rechte und Pflichten folgen aus ihrer Zugehörigkeit zur Gemeinschaft der Kirche und aus ihrer Berufung, für Christus dadurch Zeugnis zu geben, dass sie das irdische Dasein dem Willen Gottes gemäss bauen. Die Laien zeugen von der Einheit der Kirche, wenn sie am konstrutiven Dialog mit der Hierarchie teilnehmen. Besondere Rechte und Pflichten haben die Laien auf Grund des empfangenen Ehesakramentes und der Gründung einer Familie. 
Die im Projekt des neuen Kirchenrechts die Laien betreffenden rechtlichen Normen bilden eine reiche Leistung, doch bedürfen sie noch einer endgültigen Bearbeitung und Vertiefung. 